\title{
Crabapple Cultivars Tested As Street Trees: Third Report
}

\author{
Henry D. Gerhold
}

\begin{abstract}
Through the Municipal Tree Restoration Program, cooperators planted 22 crabapple (Malus) cultivars in 31 communities for evaluation as street trees, typically comparing two in each community. Standardized measurements in years $1,2,3,6,9$, and 12 revealed differences in height, crown width, and foliage health. These are useful for selecting the most appropriate cultivars for various site conditions. Only the tallest cultivars, 'Spring Snow' and 'Red Barron', have reached an average height of 6.5 to $6.7 \mathrm{~m}(21.5$ to $22 \mathrm{ft})$ in 12 years, which is still below most electric distribution lines. Yearly growth patterns varied somewhat among locations and cultivars. The rate of height growth of most cultivars has been declining during years 9 to 12, and in many cases appears to be leveling off at heights between 4 and $6 \mathrm{~m}$ (13.2 and $19.8 \mathrm{ft}$ ). Red Jewel ${ }^{\circledR}$, Sugar Tyme ${ }^{\circledR}$, and Centurion ${ }^{\circledR}$ have narrower crowns, whereas others are still enlarging. Foliage health remained good to excellent throughout the summer on all but seven of the cultivars, and even these retained more than half of their leaves in good condition.
\end{abstract}

Key Words. Crabapple cultivars; Malus; performance testing; street tree evaluation.

In 1987, the Municipal Tree Restoration Program (MTRP) started evaluating crabapple (Malus) cultivars and other species as street trees. MTRP encourages municipalities to improve their tree programs by demonstration plantings of free trees and through research provides helpful information for selecting species and cultivars that are compatible with utility wires. Previous reports (Gerhold et al. 1994; Gerhold 2000) indicated that most of the 17 crabapple cultivars that had been selected for superior disease resistance and growth habit had healthy foliage and grew well. However, many differences were found in their growth rates, and some problems had been noted.

\section{MATERIALS AND METHODS Plants and Experimental Design}

Cooperators planted the crabapple cultivars during 1987 to 1998 in 30 Pennsylvania, U.S. communities and one in Maryland. Representatives of the communities chose the planting sites with the advice of utility foresters, service foresters in the Bureau of Forestry, or Penn State extension urban foresters.

Each test planting in a community consisted of two cultivars, except for the one in Maryland, which had three cultivars, and a single cultivar in a second test in Mansfield, Pennsylvania. Typically, the paired cultivars were planted alternately within 4 to 10 plots that contained 4 to 16 trees each for a total of 48 to 50 trees. All of the trees being tested were planted along streets and under electric conductors. The local utility company arranged for the removal of any large trees that interfered with utility lines, thus making space for planting in some plots.

\section{Plant Materials}

The test trees came from several nurseries as balled-andburlapped stock, and the same nursery always supplied the two or three cultivars for a community. Calipers ranged from 4.4 to $5.1 \mathrm{~cm}$ (1.76 to 2 in) and average heights from 2.2 to $3.8 \mathrm{~m}$ ( 7.3 to $12.5 \mathrm{ft})$. The wide range in heights presumably could be explained by genetic differences among cultivars and diverse cultural differences among the nurseries that supplied the trees.

\section{Measurements and Analysis}

A trained cooperator inspected and measured the trees soon after planting, then annually during the first 3 years, and at 3 -year intervals afterward. During September or October, a service forester or extension urban forester, using standardized procedures, measured tree height, trunk diameter at breast height, and crown width; classified the health of foliage, branches, and trunk separately; and rated maintenance needs and overall quality. The health of foliage and branches was estimated according to the percentage injured using a 5 -point scale: $1=65$ to $100,2=45$ to $60,3=25$ to 40 , $4=5$ to $20,5=<5$. The scale for trunk injuries was $1=$ tree dead, $2=$ severe injuries, $3=$ moderate, $4=$ slight, $5=$ no injuries. Causes of injuries such as diseases, insects, drought, or mechanical damage were identified when possible and recorded. 
Table 1. Size and health ratings of crabapple cultivars planted as street trees, two cultivars paired at most locations ${ }^{2}$.

\begin{tabular}{|c|c|c|c|c|c|c|c|}
\hline Cultivar/abbreviation & Paired cultivar & Year & $\begin{array}{l}\text { Diam. } \\
(\mathrm{cm})\end{array}$ & $\begin{array}{l}\text { Ht. } \\
(\mathrm{m})\end{array}$ & $\begin{array}{l}\text { Width } \\
(\mathrm{m})\end{array}$ & $\begin{array}{l}\text { Foliage } \\
(1 \text { to } 5)\end{array}$ & $\begin{array}{l}\text { Branches } \\
\text { (1 to } 5)\end{array}$ \\
\hline \multirow[t]{3}{*}{ ‘Adams'/Ad } & $\mathrm{RB}$ & 12 & 9.3 & $4.1^{\mathrm{x}}$ & $4.4^{\mathrm{x}}$ & 4.5 & 4.8 \\
\hline & RJ & 9 & $14.5^{\mathrm{y}}$ & $4.8^{\mathrm{x}}$ & $5.4^{\mathrm{y}}$ & $4.4^{\mathrm{x}}$ & $4.5^{\mathrm{x}}$ \\
\hline & $\mathrm{zC}$ & 6 & $9.3^{\mathrm{y}}$ & $4.2^{\mathrm{y}}$ & 3.7 & $4.3^{\mathrm{x}}$ & 4.7 \\
\hline Am. Masterpiece ${ }^{\circledR} / \mathrm{AM}$ & $\mathrm{RB}$ & 9 & $11.7^{\mathrm{y}}$ & $5.6^{\mathrm{x}}$ & $5.5^{\mathrm{x}}$ & 2.7 & 3.8 \\
\hline \multirow[t]{3}{*}{ Am. Salute $\mathrm{TM} / \mathrm{ASa}$} & $\mathrm{HG}$ & 9 & $16.0^{\mathrm{y}}$ & $5.7^{\mathrm{y}}$ & $5.9^{\mathrm{y}}$ & $4.9^{\mathrm{y}}$ & 5.0 \\
\hline & $\mathrm{Se}$ & 9 & $11.6^{\mathrm{y}}$ & 5.4 & $5.9^{\mathrm{y}}$ & 4.9 & 5.0 \\
\hline & $\mathrm{Se}$ & 6 & 6.8 & 4.6 & 3.6 & $4.4^{\mathrm{x}}$ & 4.7 \\
\hline \multirow[t]{2}{*}{ Am. Spirit ${ }^{\mathrm{TM}} / \mathrm{ASp}$} & DW & 9 & 13.7 & 4.9 & $5.3^{\mathrm{y}}$ & 4.7 & 5.0 \\
\hline & DW & 9 & $10.7^{\mathrm{x}}$ & 4.7 & 4.3 & $4.0^{\mathrm{x}}$ & 4.6 \\
\hline Am. Triumph ${ }^{\mathrm{TM}} / \mathrm{AT}$ & none & 9 & 6.9 & 4.3 & 3.8 & 3.3 & 4.6 \\
\hline 'Beverly'/Be & RS & 6 & $7.3^{\mathrm{y}}$ & $3.6^{\mathrm{x}}$ & $3.7^{\mathrm{y}}$ & 4.1 & 4.2 \\
\hline \multirow[t]{4}{*}{ Brandywine ${ }^{\circledR} / \mathrm{Br}$} & SS & 12 & 12.5 & 5.3 & 5.7 & $3.6^{\mathrm{x}}$ & 4.7 \\
\hline & ST & 12 & $11.9^{\mathrm{y}}$ & $5.4^{\mathrm{y}}$ & $5.9^{\mathrm{y}}$ & 4.0 & 4.7 \\
\hline & Md & 12 & 17.0 & 5.7 & 6.5 & 3.7 & $4.4^{\mathrm{y}}$ \\
\hline & SS & 9 & 9.7 & $3.8^{\mathrm{x}}$ & 3.9 & $3.9^{y}$ & 4.7 \\
\hline \multirow[t]{8}{*}{ Centurion ${ }^{\circledR} / \mathrm{Ce}$} & Md, ST & 12 & $17.7^{\mathrm{y}}$ & $5.1^{\mathrm{y}}$ & $5.9^{\mathrm{y}}$ & 4.8 & 4.9 \\
\hline & $\mathrm{HG}$ & 12 & 13.9 & 4.9 & 3.8 & 4.4 & 4.7 \\
\hline & $\mathrm{HG}$ & 12 & 15.2 & $4.6^{\mathrm{x}}$ & 5.2 & $4.6^{\mathrm{y}}$ & 4.9 \\
\hline & $\mathrm{Sn}$ & 12 & $11.6^{\mathrm{x}}$ & 4.5 & $4.7^{\mathrm{x}}$ & $3.7^{\mathrm{y}}$ & 3.7 \\
\hline & SS & 12 & $14.2^{\mathrm{x}}$ & $4.7^{\mathrm{x}}$ & $4.7^{\mathrm{x}}$ & 4.5 & 4.8 \\
\hline & ST & 12 & 8.7 & 4.0 & 4.5 & 4.0 & 4.9 \\
\hline & $\mathrm{RB}$ & 12 & $18.2^{\mathrm{y}}$ & 6.0 & $6.9^{\mathrm{y}}$ & 4.4 & 4.9 \\
\hline & $\mathrm{RB}$ & 12 & $11.3^{\mathrm{y}}$ & $4.6^{\mathrm{x}}$ & 5.4 & 4.5 & 4.8 \\
\hline \multirow[t]{3}{*}{ 'Donald Wyman'/DW } & SS & 12 & $14.9^{\mathrm{x}}$ & $4.8^{\mathrm{x}}$ & $7.0^{\mathrm{y}}$ & 4.9 & 5.0 \\
\hline & $\mathrm{ASp}$ & 9 & 13.6 & 4.6 & $4.9^{\mathrm{x}}$ & 4.8 & 5.0 \\
\hline & $\mathrm{ASp}$ & 9 & $13.8^{\mathrm{y}}$ & 4.6 & 4.6 & $4.5^{\mathrm{y}}$ & 4.8 \\
\hline \multirow[t]{8}{*}{ Harvest Gold ${ }^{\circledR} / \mathrm{HG}$} & $\mathrm{RJ}$ & 12 & $12.9^{\mathrm{y}}$ & $5.1^{\mathrm{y}}$ & $4.9^{\mathrm{y}}$ & $3.6^{\mathrm{x}}$ & 4.1 \\
\hline & $\mathrm{Ce}$ & 12 & 12.7 & 4.9 & 4.1 & 4.4 & 4.7 \\
\hline & ST & 12 & 15.3 & $5.3^{\mathrm{y}}$ & $5.0^{\mathrm{y}}$ & 4.3 & 4.9 \\
\hline & $\mathrm{Ce}$ & 12 & 15.4 & $5.0^{\mathrm{y}}$ & 5.3 & $3.9^{\mathrm{x}}$ & 4.8 \\
\hline & $\mathrm{RB}$ & 12 & 13.8 & 6.0 & 5.6 & 4.8 & 5.0 \\
\hline & Md & 12 & 14.5 & 5.9 & 5.6 & $4.4^{\mathrm{y}}$ & 4.8 \\
\hline & $\mathrm{ASa}$ & 9 & $11.9^{\mathrm{x}}$ & $5.1^{\mathrm{x}}$ & $4.9^{\mathrm{x}}$ & $4.2^{\mathrm{x}}$ & 4.9 \\
\hline & $\mathrm{Sn}$ & 3 & $3.4^{\mathrm{x}}$ & 3.4 & - & $3.2^{\mathrm{x}}$ & 3.9 \\
\hline Holiday Gold ${ }^{\mathrm{TM}} / \mathrm{HoG}$ & $\mathrm{Se}$ & 9 & $6.9^{\mathrm{x}}$ & $4.2^{\mathrm{x}}$ & 3.1 & 4.8 & 4.9 \\
\hline \multirow[t]{3}{*}{ Madonna ${ }^{\circledR} / \mathrm{Md}$} & $\mathrm{Ce}, \mathrm{ST}$ & 12 & $9.9^{\mathrm{x}}$ & $4.4^{\mathrm{x}}$ & 4.5 & 4.5 & 4.9 \\
\hline & $\mathrm{HG}$ & 12 & 13.3 & 5.7 & 5.2 & $3.6^{\mathrm{x}}$ & 4.6 \\
\hline & $\mathrm{Br}$ & 12 & 12.0 & 5.6 & 5.6 & 3.8 & $3.6^{\mathrm{x}}$ \\
\hline 'Prairifire'/Pr & RJ & 12 & $11.1^{\mathrm{x}}$ & $4.9^{\mathrm{x}}$ & 5.3 & 4.9 & 5.0 \\
\hline \multirow[t]{6}{*}{ 'Red Barron'/RB } & $\mathrm{RJ}$ & 12 & 12.0 & $5.7^{\mathrm{y}}$ & 4.4 & 4.6 & 4.9 \\
\hline & $\mathrm{HG}$ & 12 & $12.9^{\mathrm{x}}$ & 6.5 & 5.8 & 4.8 & 5.0 \\
\hline & Ad & 12 & 7.8 & $5.3^{\mathrm{y}}$ & $5.2^{\mathrm{y}}$ & 4.4 & 4.8 \\
\hline & $\mathrm{Ce}$ & 12 & $14.3^{\mathrm{x}}$ & 6.1 & $6.8^{\mathrm{x}}$ & 4.6 & 4.9 \\
\hline & $\mathrm{Ce}$ & 12 & $9.9^{\mathrm{x}}$ & $5.3^{\mathrm{y}}$ & 5.0 & 4.4 & 4.9 \\
\hline & $\mathrm{AM}$ & 9 & $10.0^{\mathrm{x}}$ & $6.6^{\mathrm{y}}$ & $6.2^{\mathrm{y}}$ & 3.0 & 3.7 \\
\hline \multirow[t]{6}{*}{ Red Jewel ${ }^{\circledR} /$ RJ } & $\mathrm{HG}$ & 12. & $9.6^{\mathrm{x}}$ & $3.8^{\mathrm{x}}$ & $3.6^{\mathrm{x}}$ & $3.9^{\mathrm{y}}$ & 4.1 \\
\hline & $\mathrm{RB}$ & 12 & 10.1 & $4.8^{\mathrm{x}}$ & 4.4 & $4.6^{\mathrm{y}}$ & 4.9 \\
\hline & ST & 12 & $6.6^{\mathrm{x}}$ & $3.9^{\mathrm{y}}$ & 3.6 & 4.7 & 4.5 \\
\hline & Ad & 9 & $11.3^{\mathrm{x}}$ & 4.7 & $4.7^{\mathrm{x}}$ & $4.8^{\mathrm{y}}$ & $5.0^{\mathrm{y}}$ \\
\hline & $\operatorname{Pr}$ & 12 & $16.3^{\mathrm{y}}$ & $5.9^{\mathrm{y}}$ & 6.0 & 4.8 & 5.0 \\
\hline & $\mathrm{Se}$ & 9 & $11.0^{\mathrm{x}}$ & $4.2^{\mathrm{x}}$ & $4.3^{\mathrm{x}}$ & 4.2 & 4.3 \\
\hline Royal Scepter ${ }^{\mathrm{TM}} / \mathrm{RS}$ & $\mathrm{Be}$ & 6 & $6.4^{\mathrm{x}}$ & $4.6^{\mathrm{y}}$ & $2.7^{\mathrm{x}}$ & 3.8 & 4.0 \\
\hline \multirow{2}{*}{ 'Sentinel'/Se } & $\mathrm{RJ}$ & 9 & $14.6^{\mathrm{y}}$ & $5.2^{\mathrm{y}}$ & $5.9^{\mathrm{y}}$ & 4.1 & 4.1 \\
\hline & HoG & 9 & $8.7^{\mathrm{y}}$ & $4.9^{\mathrm{y}}$ & 3.0 & 4.9 & 4.9 \\
\hline
\end{tabular}


Table 1. Size and health ratings of crabapple cultivars planted as street trees, two cultivars paired at most locations ${ }^{2}$ (continued).

\begin{tabular}{|c|c|c|c|c|c|c|c|}
\hline Cultivar/abbreviation & Paired cultivar & Year & $\begin{array}{l}\text { Diam. } \\
(\mathrm{cm})\end{array}$ & $\begin{array}{l}\text { Ht. } \\
(\mathrm{m})\end{array}$ & $\begin{array}{l}\text { Width } \\
\text { (m) }\end{array}$ & $\begin{array}{l}\text { Foliage } \\
(1 \text { to } 5)\end{array}$ & $\begin{array}{l}\text { Branches } \\
\text { (1 to 5) }\end{array}$ \\
\hline \multirow{5}{*}{ 'Snowdrift'/Sn } & $\mathrm{ASa}$ & 6 & 6.3 & 4.0 & 3.3 & $4.9^{y}$ & 4.8 \\
\hline & $\mathrm{ASa}$ & 9 & $10.0^{\mathrm{x}}$ & 5.0 & $5.0^{\mathrm{x}}$ & 4.8 & 4.9 \\
\hline & $\mathrm{zC}$ & 12 & $12.9^{\mathrm{x}}$ & 4.9 & $5.4^{\mathrm{x}}$ & $3.7^{x}$ & 4.1 \\
\hline & $\mathrm{Ce}$ & 12 & $13.3^{y}$ & 4.6 & $5.4^{\mathrm{y}}$ & $3.4^{\mathrm{x}}$ & 3.8 \\
\hline & HG & 3 & $4.3^{\mathrm{y}}$ & 3.4 & - & $3.6^{y}$ & 3.8 \\
\hline \multirow{4}{*}{ 'Spring Snow'/SS } & $\mathrm{Br}$ & 12 & 11.9 & 5.7 & 5.1 & $4.0^{\mathrm{y}}$ & 4.8 \\
\hline & DW & 12 & $17.5^{\mathrm{y}}$ & $5.4^{\mathrm{y}}$ & $5.2^{\mathrm{x}}$ & 4.6 & 4.9 \\
\hline & $\mathrm{Ce}$ & 12 & $23.9^{\mathrm{y}}$ & $6.7^{\mathrm{y}}$ & $6.2^{\mathrm{y}}$ & 4.6 & 4.8 \\
\hline & $\mathrm{Br}$ & 9 & 10.8 & $4.2^{\mathrm{y}}$ & 3.4 & $3.6^{x}$ & 4.6 \\
\hline \multirow[t]{6}{*}{ Sugar Tyme ${ }^{\circledR} / \mathrm{ST}$} & $\mathrm{Ce}, \mathrm{Md}$ & 12 & $20.4^{\mathrm{y}}$ & $5.6^{\mathrm{y}}$ & $6.7^{\mathrm{y}}$ & 4.8 & 4.9 \\
\hline & $\mathrm{HG}$ & 12 & 15.0 & $4.5^{\mathrm{x}}$ & 4.8 & 4.6 & 4.7 \\
\hline & $\mathrm{Br}$ & 12 & $9.4^{x}$ & $4.0^{\mathrm{x}}$ & $4.0^{\mathrm{x}}$ & 4.0 & 4.7 \\
\hline & RJ & 12 & $8.0^{y}$ & $3.4^{x}$ & 3.4 & 4.6 & 4.7 \\
\hline & $\mathrm{Ce}$ & 12 & 8.4 & 3.8 & 4.2 & 4.0 & 4.8 \\
\hline & VP & 12 & 11.9 & $4.2^{\mathrm{x}}$ & 4.3 & $4.7^{\mathrm{y}}$ & 4.9 \\
\hline \multirow{3}{*}{$\begin{array}{l}\text { Velvet Pillar'TM/VP } \\
\text { zumi 'Calocarpa'/zC }\end{array}$} & ST & 12 & 14.6 & $5.1^{\mathrm{y}}$ & 4.7 & $3.2^{\mathrm{x}}$ & 4.8 \\
\hline & $\mathrm{Sn}$ & 12 & $14.9^{\mathrm{y}}$ & 5.2 & $5.8^{\mathrm{y}}$ & $4.0^{\mathrm{y}}$ & 4.2 \\
\hline & $\mathrm{Ad}$ & 9 & $7.6^{\mathrm{x}}$ & $3.8^{x}$ & 3.6 & $4.7^{\mathrm{y}}$ & 4.7 \\
\hline
\end{tabular}

${ }^{\mathrm{z}}$ Average trunk diameter, tree height, and crown width are in the most advanced year; foliage health and branch health ratings are averaged over all years: 1 , $2,3,6,9$, and 12 in most cases.

${ }^{\mathrm{y}}$ Significantly greater at $95 \%$ level than corresponding value of the paired cultivar.

${ }^{\mathrm{x}}$ Significantly smaller at $95 \%$ level than corresponding value of the paired cultivar. Foliage and branch health ratings: $1=65 \%$ to $100 \%$ of leaves or branches exhibit injury, $2=45 \%$ to $60 \%, 3=25 \%$ to $40 \%, 4=5 \%$ to $20 \%, 5=$ less than $5 \%$.

An analysis of variance (using MINITAB's General Linear Model) of quantitative data collected in a given year calculated means and determined statistical differences between the cultivars at a particular location at the 5\% level of probability. Each test location in every year constituted a separate experiment with plots providing replication within a community. These results, along with comments provided by cooperators, were used to characterize performance of the cultivars.

\section{RESULTS}

Many of the cultivars paired with each other in a community differed significantly in average tree height, crown width, or trunk diameter (Table 1). All had survival rates of $84 \%$ to $100 \%$ for the first 3 years and therefore were tolerant of stressful conditions along streets. Twelve years after planting, average tree heights of cultivars in municipalities varied from 3.4 to $6.7 \mathrm{~m}$ (11.2 to $22 \mathrm{ft}$ ) and crown widths from 3.4 to $7 \mathrm{~m}$ (11.2 to $23 \mathrm{ft})$. The rate of growth in tree height generally was less from the ninth to the 12 th year than in the period of most rapid growth, between the third and ninth years (Figure 1); similar patterns of height growth were found for shorter and taller cultivars. The declining rate of height growth indicates that total height probably will not increase much more after the 12th year, although there may be exceptions such as Harvest Gold ${ }^{\circledR}$ at Mansfield (Figure 2).

The most reliable data are for those cultivars evaluated for the longest time at multiple locations. Comparisons among any cultivars that were not planted together at the same location could be confounded by interaction of cultivars by locations, i.e., their effects are inseparable. Among those cultivars that had been tested for 12 years in several municipalities, 'Spring Snow' and 'Red Barron' were the tallest; Brandywine ${ }^{\circledR}$, Harvest Gold ${ }^{\circledR}$, and Madonna ${ }^{\circledR}$ were nearly as tall; Centurion ${ }^{\circledR}$ and 'Snowdrift' were shorter; and Red Jewel ${ }^{\circledR}$ and Sugar Tyme ${ }^{\circledR}$ were the shortest. Concerning the cultivars that have not been tested as long or in as many places, it appears that American Salute ${ }^{\mathrm{TM}}$ and American Masterpiece ${ }^{\circledR}$ will be among the tallest; American Spirit ${ }^{\mathrm{TM}}$, 'Adams', 'Sentinel', 'Donald Wyman', zumi 'Calocarpa', Royal Scepter ${ }^{\mathrm{TM}}$, 'Prairifire', and American Tri$\mathrm{umph}^{\mathrm{TM}}$ will be intermediate in height; and 'Beverly', Holiday Gold ${ }^{\mathrm{TM}}$, and Velvet Pillar ${ }^{\mathrm{TM}}$ will be among the shortest, more or less in that order.

Patterns of height growth can vary appreciably among locations as illustrated by four trend lines of Harvest Gold ${ }^{\circledR}$ (Figure 2). The trees at Lawrenceville and Mansfield, which are 20 miles apart in northern Pennsylvania, came from the same nursery and were planted in 1993; the cause of the 


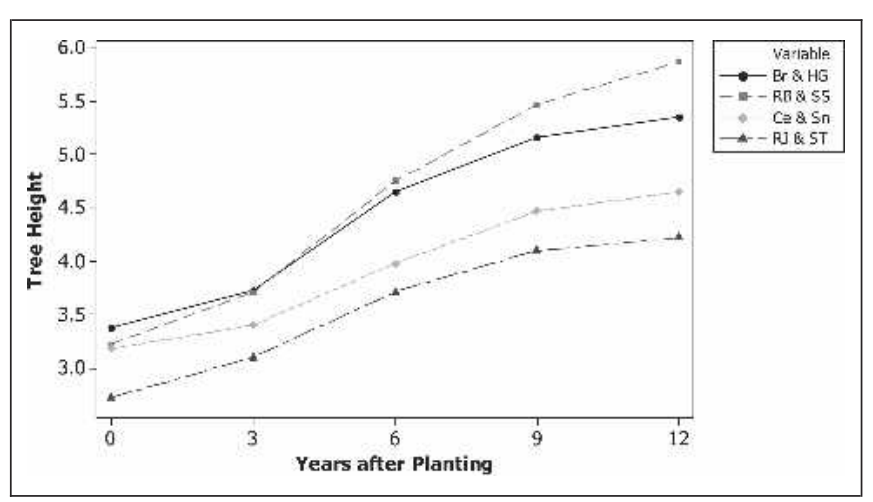

Figure 1. Average heights $(\mathrm{m})$ of similar pairs of crabapple cultivars. $\mathrm{Br}=$ Brandywine $^{\circledR} ; \mathrm{HG}=$ Harvest Gold ${ }^{\circledR} ; \mathrm{RB}=$ Red Baron; SS = Spring Snow; $\mathrm{Ce}=$ Centurion ${ }^{\circledR} ;$ Sn $=$ Snowdrift; RJ = Red Jewel ${ }^{\circledR} ;$ ST $=$ Sugar Tyme ${ }^{\circledR}$.

divergence after the ninth year is unknown. Those at Bellefonte (central Pennsylvania) and Leechburg (west central Pennsylvania) were planted in 1994 and came from two other nurseries. During years 0 to 3 and 9 to 12 , the lines differ markedly from the average growth of the cultivar, which closely resembles the line for Brandywine ${ }^{\circledR}$ and Harvest Gold $^{\circledR}$ in Figure 1. There was nothing in the recorded site conditions or observations of the trees that could explain these departures from average growth.

Average trunk diameters also differed between pairs of cultivars (Table 1). Larger trunks were associated with taller trees or wider crowns and generally appeared to be sturdy enough to support them.

Although crown widths were not measured in the first few years, it is apparent that widths and growth patterns varied among cultivars and locations as much as did their heights. For example, the spread of Harvest Gold ${ }^{\circledR}$ at four locations (Figure 3) enlarged greatly from the third to the sixth year, did not increase much at three locations during the next 3

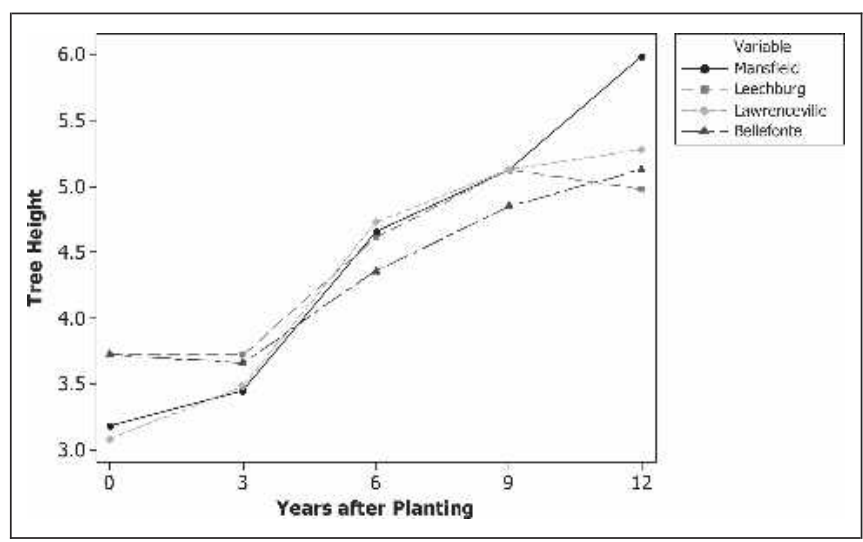

Figure 2. Average heights $(m)$ of Harvest Gold $^{\circledR}$ at four locations.

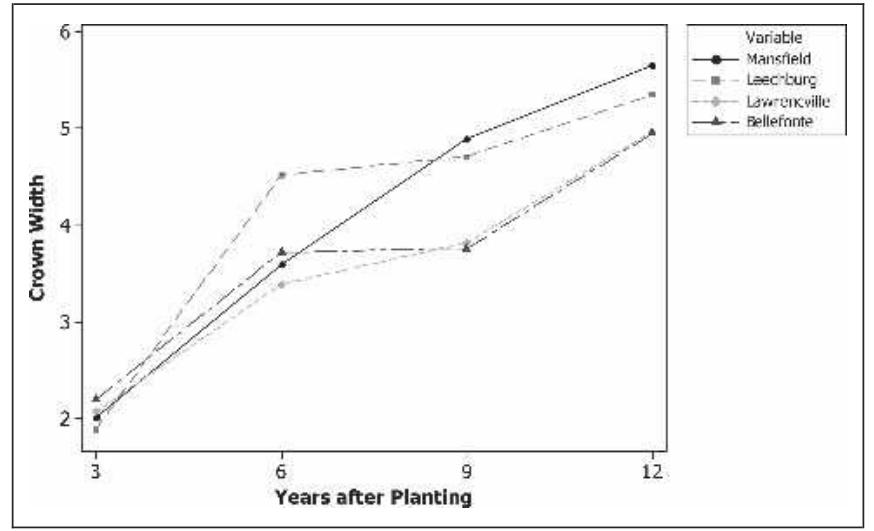

Figure 3. Average crown widths $(\mathrm{m})$ of Harvest Gold ${ }^{\circledR}$ at four locations.

years, and then accelerated again until the 12th year. Some growth patterns seem to have leveled off by the ninth or 12th year, whereas others were still growing steeply (Figure 4); the patterns of cultivars are of course confounded with location effects such as those in Figures 2 and 3. The steeper increase by 'Donald Wyman' after the ninth year probably was a response to a change in site conditions, because the pattern for the companion cultivar 'Spring Snow' was similar. Although it may be too early to project the ultimate widths of many of the cultivars, the small sizes and declining growth rates of Red Jewel ${ }^{\circledR}$, Sugar Tyme ${ }^{\circledR}$, and Centurion ${ }^{\circledR}$ do indicate that they will remain narrower than the others.

Most of the cultivars consistently had healthy foliage over the years, many of them growing at multiple locations (Table 1 ). The best ones with average ratings of 4.5 or better, in descending order, were noted for 'Prairifire' (one location), American Salute ${ }^{\mathrm{TM}}$, 'Donald Wyman', Holiday Gold ${ }^{\circledR}$ (one location), 'Sentinel', and Sugar Tyme ${ }^{\circledR}$. The lowest average

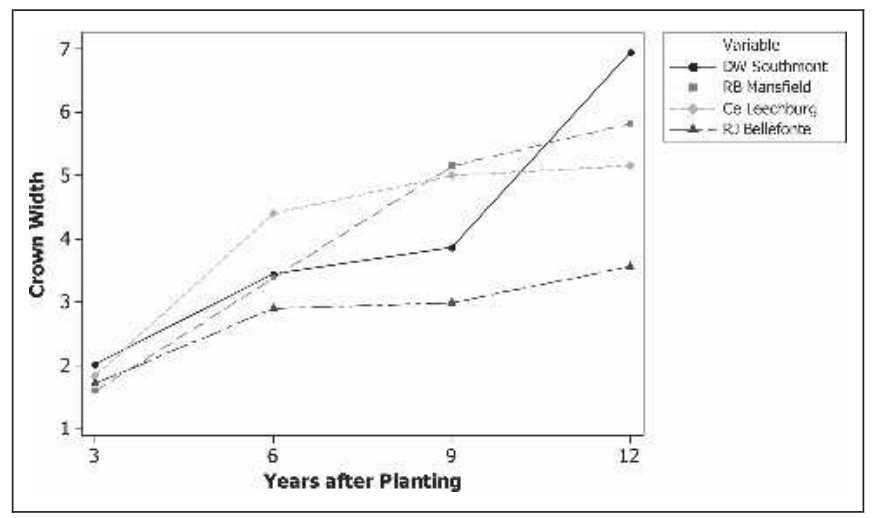

Figure 4. Average crown widths $(m)$ of four cultivars at four locations. DW = Donald Wyman; RB = Red Baron; $\mathrm{Ce}=$ Centurion $^{\circledR} ; \mathrm{RJ}=$ Red Jewel ${ }^{\circledR}$. 
ratings below 4.0, in ascending order, were given to American Masterpiece ${ }^{\circledR}$ (one location), American Triumph ${ }^{\mathrm{TM}}$ (one location), Velvet Pillar' ${ }^{\mathrm{TM}}$, 'Snowdrift', Royal Scepter ${ }^{\mathrm{TM}}$ (one location), Brandywine ${ }^{\circledR}$, and Madonna ${ }^{\circledR}$. However, even these only had injuries to less than half of their foliage at the end of the growing season. None of the cultivars had serious health problems with their branches. Trunk injuries were caused mainly by mowers and vehicles, seldom serious, and not associated with cultivars; therefore, they are not reported.

Several kinds of injuries and other problems were observed. Foliage injuries were caused variously by apple scab (Venturia inaequalis), Japanese beetle (Popillia japonica), fall webworm (Hyphantria cunea), and gypsy moth (Lymantria dispar); cultivar differences in one or more of these are reflected in the foliage health ratings. Basal sprouting, which is unsightly if not removed by pruning, occurred in many of the cultivars, perhaps all; sprouting was not routinely recorded. A more serious need for pruning occurred where the lower branches of the shorter and broader cultivars planted close to streets or sidewalks interfered with pedestrians, vehicles, and visibility. The fruit of some cultivars was messy when it fell on sidewalks and could be treacherous to pedestrians, especially that of Brandywine ${ }^{\circledR}$, which was 1 in or more in diameter. However, most cultivars had attractive fruit $1 / 4$ to $3 / 8$ in in diameter, which in some cases persisted well into the winter; fruit of Madonna ${ }^{\circledR}$, however, quickly lost its color.

Extensive evaluations of crabapple cultivars for disease resistance and aesthetic qualities in Ohio (Chatfield et al. 1999, 2002), and at 25 locations in the national crabapple evaluation program (Green 1994; Den Boer and Green 1995) were not entirely consistent with each other nor with the evaluations in Pennsylvania. In fact, some cultivars that were dropped from the Ohio program-'Adams', Centurion ${ }^{\circledR}$, 'Red Barron', and Velvet Pillar ${ }^{\circledR}$ - performed quite well under our street-side conditions. It is apparent that disease resistance varies among years and geographic regions and also with local site conditions. Aesthetic criteria and desirability of form and branching characteristics undoubtedly differed among the various studies too.

\section{CONCLUSIONS}

Most of the cultivars that were evaluated as street trees have proven to be very successful with attractive flowers, fruit, and healthy foliage. Even the tallest ones are compatible with overhead wires and will require little or no pruning for clearance. Pruning will be needed to remove basal sprouts and lower branches as trees grow, particularly branches that interfere with pedestrians, vehicles, and visibility for safety.

Recommended cultivars, limited to those evaluated at three or more locations, include 'Adams', American Salute ${ }^{\mathrm{TM}}$, Centurion ${ }^{\circledR}$, 'Donald Wyman', Harvest Gold ${ }^{\circledR}$, ‘Red Barron', Red
Jewel ${ }^{\circledR}$, 'Sentinel', 'Snowdrift', 'Spring Snow', and 'Sugar Tyme ${ }^{\circledR}$.

Others that appear promising include American Masterpiece $^{\circledR}$, American Spirit ${ }^{\mathrm{TM}}$, American Triumph ${ }^{\mathrm{TM}}$, 'Beverly', Holiday Gold ${ }^{\circledR}$, 'Prairifire', zumi 'Calocarpa', and perhaps Royal Scepter ${ }^{\mathrm{TM}}$ and Velvet Pillar ${ }^{\mathrm{TM}}$ if foliage health proves to be adequate.

When any of these crabapples are selected for particular sites, their size, growth rate, and branching habit should be considered in relation to space limitations along with attractive features such as flowers and fruit. There are many useful references that provide more complete information about cultivar characteristics, including Michael (1990), Green (1994), Chatfield et al. (1999), Dirr (1998), Gerhold et al. (2001), and Gerhold (2005).

Acknowledgments. Financial support for the Municipal Tree Restoration Program was provided by Allegheny Energy, Asplundh Tree Expert Company, Baltimore Gas \& Electric Company, Bartlett Tree Expert Company, Duquesne Light Company, First Energy Company, Hazlett Tree Service, PECO Energy Company, PPL Electric Utilities, and UGI Utilities. Foresters of the Pennsylvania Bureau of Forestry and Extension Urban Foresters of Penn State University assisted with community liaison and tree measurements.

\section{LITERATURE CITED}

Chatfield, J.A., E.A. Draper, K.D. Cochran, P.W. Bristol, and D.E. Allen. 1999. Comprehensive aesthetic evaluations of crabapples at Secrest Arboretum in Wooster: 1993-1998. Ohio State University, Ohio Agricultural Research and Development Center, Special Circular 165-99.

Chatfield, J.A., E.A. Draper, D.A. Herms, and K.D. Cochran. 2002. Apple scab on crabapples at the Secrest Arboretum: 2001. Ohio State University, Ohio Agricultural Research and Development Center, Special Circular 186-02.

Den Boer, J.H., and T.L. Green. 1995. Disease and aesthetic ratings. Malus. International Ornamental Crabapple Bulletin 9:8-56.

Dirr, M.A. 1998. Manual of Woody Landscape Plants. Stipes Publishing, Champaign, IL. 1187 pp.

Gerhold, H.D. 2000. Crabapple cultivars tested as street trees: Second report. Journal of Arboriculture 26:48-59.

- 2005. Landscape Tree Factsheets CD. School of Forest Resources, University Park, PA.

Gerhold, H.D., N.L. Lacasse, and W.N. Wandell. 2001. Landscape Tree Factsheets. College of Agricultural Sciences, University Park, PA. 456 pp.

Gerhold, H.D., H.L. McElroy, and H.L.H. Rhodes. 1994. Street tree performance tests of crabapple cultivars: Initial results. Journal of Arboriculture 20:87-93.

Green, T.L. 1994. Results of the national crabapple evaluation program. Proceedings of the Metropolitan Tree Improvement Alliance 8:1-8. 
Michael, A.H. 1990. Flowering crabapples. Penn State University, Ornamentals and Turf Newsletter 2:4-5.

\author{
Henry D. Gerhold \\ Professor of Forest Genetics \\ Pennsylvania State University \\ School of Forest Resources \\ 333 Forest Resources Building \\ University Park, PA 16802, U.S. \\ hdg@psu.edu
}

Résumé. Avec le Programme municipal de restauration des arbres, les coopérateurs ont planté 22 cultivars de pommetiers (Malus) au sein de 31 municipalités afin d'en faire l'évaluation comme arbre de rue, et ce en les comparant deux par deux par ville. Les mesures standardisées prises au cours des années 1, 2, 3, 6, 9 et 12 ont permis de révéler des différences dans la hauteur, la largeur de la cime et l'état de santé du feuillage. Ces données sont utiles pour sélectionner le cultivar le plus approprié selon les différentes conditions de site. Seuls les plus grands cultivars, 'Spring Snow' et Red Barron' ont atteint des hauteurs moyennes de 6,5 à $6,7 \mathrm{~m}$ en 12 ans, ce qui est toujours sous le niveau de la plupart des réseaux électriques de distribution. La patron de croissance annuelle variait quelque peu entre les divers sites et les cultivars. Le taux de croissance en hauteur de la plupart des cultivars diminuait au cours des années 9 à 12, et dans plusieurs cas il apparaissait se stabiliser à des hauteurs entre 4 et $6 \mathrm{~m}$. Les cultivars Red Jewel ${ }^{\circledR}$, Sugar Tyme ${ }^{\circledR}$ et Centurion ${ }^{\circledR}$ avaient des cimes plus étroites tandis que les autres continuaient à s'élargir. La santé du feuillage demeurait de bonne à excellente durant tout l'été chez tous les cultivars sauf sept, et même ces derniers avaient plus de la moitié de leur feuillage qui demeurait en bonne santé.

Zusammenfassung. Durch das kommunale Baumpflanzprogramm pflanzten die Teilnehmer 22 Apfelkultivare in 31 Gemein- den, um sie als Straßenbäume zu bewerten, wobei in jeder Kommune zwei verglichen wurden. Standardisierte Messungen in den Jahren 1, 2, 3, 6, 9 und 12 ergaben Unterschiede in der Höhe, Kronenbreite und Blattgesundheit. Diese sind wichtig für die Auswahl der geeigneten Kultivare für unterschiedliche Standorte. Nur die größten Kultivare, ,Spring Snow“ und „Red Baron“, haben eine durchschnittliche Höhe von $6,5 \mathrm{~m}$ bis $6,7 \mathrm{~m}$ in 12 Jahren erreicht, was immer noch unter den meisten Elektroleitungen liegt. Die jährlichen Wachstumsmuster variierten etwas zwischen den Lokalitäten und Kultivaren. Die Rate des Höhenwachstums der meisten Kultivare ging während der Jahre 9 bis 12 zurück und in vielen Fällen schien es sich auf einem Level von 4 bis $6 \mathrm{~m}$ einzustellen. „Red Jewel“, „Sugar Tyme“ und „Centurion“ hatten engere Kronen, während die anderen sich immer mehr ausbreiteten. Die Blattgesundheit hielt sich gut bis exzellent über den Sommer bei allen Kultivaren bis auf sieben und auch diese behielten mehr als die Hälfte ihrer Blätter in guter Kondition.

Resumen. A través del Programa Municipal de Árboles los cooperadores plantaron 22 cultivares de manzanos (Malus) en 31 comunidades para su evaluación como árboles urbanos, comparando típicamente dos en cada comunidad. Las mediciones estandarizadas en los años 1, 2, 3, 6, 9 y 12 revelaron diferencias en altura, diámetro de la copa y salud del follaje. Estas evaluaciones son útiles para seleccionar los cultivares más apropiados para varias condiciones del sitio. Solamente los cultivares más altos, 'Spring Snow' y 'Red Barron', han alcanzado una altura promedio de 6.5 a $6.7 \mathrm{~m}$ en doce años, lo cual es aún bajo para las líneas de conducción eléctrica. Los patrones de crecimiento anuales variaron entre localidades y cultivares. La tasa de crecimiento en altura de la mayoría de los cultivares ha estado declinando durante los años 9 a 12, y en muchos casos parece estar nivelándose a alturas ente 4 y 6 metros. Red Jewel ${ }^{\circledR}$, Sugar Tyme ${ }^{\circledR}$, y Centurion ${ }^{\circledR}$ tienen copas estrechas, mientras que los otros aún están ampliándose. La salud del follaje es de buena a excelente a través del verano en todos a excepción de siete cultivares, pero aún en estos más de la mitad de sus hojas permanecen en buena condición. 